\title{
Phosphatase Hydrolysis of Organic Phosphorus Compounds
}

\author{
Irenus A. Tazisong1* , Zachary N. Senwo', Zhongqi He ${ }^{2}$ \\ ${ }^{1}$ Department of Biological \& Environmental Sciences, Alabama A\&M University, Normal, AL, USA \\ ${ }^{2}$ USDA-ARS Southern Regional Research Center, New Orleans, LA, USA \\ Email: irenus.tazisong@aamu.edu, zachary.senwo@aamu.edu, zhongqi.he@ars.usda.gov
}

Received 31 March 2015; accepted 19 June 2015; published 24 June 2015

Copyright (C) 2015 by authors and Scientific Research Publishing Inc.

This work is licensed under the Creative Commons Attribution International License (CC BY). http://creativecommons.org/licenses/by/4.0/

(c) (i) Open Access

\begin{abstract}
Phosphatases are diverse groups of enzymes that deserve special attention because of their significant roles in organic phosphorus (OP) mineralization to inorganic available forms (Pi). This work 1) compared the catalytic potentials of commercially acid phosphatase from wheat germ, sweet potato, and potato, and alkaline phosphatase from $E$. coli; 2) demonstrated that the rate of hydrolysis, catalytic efficiency, thermal stability, and optimal pH of these enzymes depended on enzyme sources and the stereochemical or stereoisomeric structures of the substrates; 3 ) revealed that both acid and alkaline phosphatases exhibited broad range of substrate hydrolysis with high affinity for $p$-nitrophenyl phosphate bis (cyclohexylammonium) than the widely used $p$-nitrophenyl phosphate disodium hexahydrate for phosphatase assay. Sweet potato had relatively higher reaction kinetics $\left(V_{\text {max }}, K_{\mathrm{m}}, K_{\text {cat }}, K_{\text {cat }} / K_{\mathrm{m}}\right)$ values with most substrates tested. The order of catalytic activity was in the order: sweet potato $>$ wheat germ $>$ potato, while the order of substrate hydrolyzed was: PNPBC > PNP > PNP2A2E > DG6P2Na > DG6PNa > Bis-PNP > phytate. The optimum pH for the acid phosphatase was observed to be 5.0. Generally, the activity of alkaline phosphatase was similar to that of acid phosphatase with optimal pH between 10 and 13 , depending on the substrates. Knowledge derived from this work would be helpful in enzyme catalysis in soils and water environments.
\end{abstract}

\section{Keywords}

Enzymes, Phosphatases, Organic Phosphorus Mineralization, Wheat Germ, Sweet Potato, E. coli

\section{Introduction}

Phosphatases are diverse groups of enzymes that deserve special attention because of their significant roles in

"Corresponding author. 
organic phosphorus (OP) mineralization to inorganic available forms [1]-[4]. These enzymes have been classified into five major groups: (phosphoric monoester hydrolases (EC 3.1.3); phosphoric diester hydrolases (EC 3.1.4); triphosphoric monoester hydrolases (EC 3.1.5); polyphosphate hydrolase (EC 3.1.8); and phosphoamidase (EC 3.9.1.1), depending on the bonds they cleave [5].

While phosphatases generally hydrolyze phosphoric $\left(\mathrm{H}_{3} \mathrm{PO}_{4}\right)$ esters and anhydrides to release phosphate, they differ in their pH optima, metal ion requirements, substrate specificities, and reaction mechanisms. Acid and alkaline phosphatases have been used to mineralize specific OP compounds in animal manure, soils, water, and sediments [6]-[12]. Both acid and alkaline phosphatases are known to hydrolyze a variety of phosphomono esters. The hydrolysis of organic P compounds using specific phosphatase enzymes both in soils and biological systems is vital for energy metabolisms, metabolic regulations, and cellular signal transductions pathways [13]-[16].

Low P availability in soils may trigger phosphatase secretions to the rhizosphere; however, soil phosphatases are sometimes derived from 1) intracellular enzymes or enzymes bound to cell components and 2) abiotic or extracellular enzymes leaking from intact cells or released from dead or lysed cells that originate from the cell membrane [17]. It has been shown that acid phosphatase in soils are of both plant and microbial origins, while alkaline phosphatase is mostly of microbial origin [4] [18]. Significant positive correlation between alkaline phosphatase activity and soil bacterial populations have been reported [19]. The dephosphorylation of OP compounds in soils largely depends on the stereochemical and stereoisomeric structures of the OP compounds in question, in addition to the type and enzyme sources involved in such catalytic hydrolysis. The high affinity of some enzymes for particular substrates has been used as the basis to identify and quantify specific OP compounds, or as part of post separation quantification step [20]-[23]. Strickland and Solorzano [24] used alkaline phosphatase to assess bioavailable $\mathrm{P}$ hydrolyzed by exocellular algal phosphatase released due to phosphate depletion.

A distinctive feature of alkaline phosphatase is the presence of two $\mathrm{Zn}^{2+}$ and one $\mathrm{Mg}^{2+}$ ions per sub unit [25], [26] which is lacking in acid phosphatase [13]. Our understanding of the precise role and function of phosphatase enzymes in mineralizing OP in soils is constrained to some extent by limitations of the methods used since there is no standard method to determine soil enzyme reactions or hydrolysis. Para-nitrophenyl phosphate and bis-para-nitrophenyl have been widely used to assay soil phosphomonoesterase and phosphodiesterase activities [27]. Although para-nitrophenyl has been commonly used to assay soil phosphatase hydrolysis, this may not accurately reflect the relative hydrolysis of various soil phosphohydrolases [28]. Thus, understanding the behavior of enzymes in pure systems with different substrates would improve our understanding of enzyme hydrolysis in soils and water environments. Such studies may enhance our understanding of the contributions of individual enzymes to specific reactions in soils and water environments, and enable predicting the status of key reactions participating in rate limiting steps during the decomposition or degradation of organic materials and transformation of elements [11] [20] [29]. Previously, we have investigated the hydrolysis of organic phosphates by commercially available phytase from wheat and fungi [30]. With this study, we have focused on commercially available acid phosphatase from wheat germ, sweet potato, and potato, and alkaline phosphatase from E. coli that catalyze simple monoester bond. These four enzymes are selected because some have been used in characterizing and quantifying OP in various environmental samples [22] [29] [31] [32]. The goals are to show that: 1) phosphatase enzyme catalytic efficiency and thermal stability are functions of the enzyme sources and the type of substrates involved, and 2) phosphatase enzyme exhibits broad range of substrate hydrolysis.

\section{Materials and Methods}

\subsection{Organic Phosphate Compounds and Enzymes}

$P$-nitrophenyl phosphate disodium hexahydrate ( $>97 \%$ ) (PNP), $p$-nitrophenyl phosphate di (2-amino-2-ethyl-1, 3 propanediol) (PNP2A2E), $P$-nitrophenyl phosphate bis (cyclohexylammonium) (PNPBC), Bis $p$-nitrophenyl phosphate sodium (Bis-PNP), D-glucose 6-phosphate sodium salt (98\%) (DG6PNa), D-glucose 6-phosphate disodium hydrate (98\% - 100\%) (DG6P2Na), and inositol hexakisphosphate (phytic acid sodium salt) substrates are shown in Figure 1, and acid phosphatase from wheat germ, sweet potato, and potato (EC 3.1.3.2; 0.4, 14, and $1 \mathrm{U} \cdot \mathrm{mg}^{-1}$ ), and alkaline phosphatase from E. coli type III (EC 3.1.3.1, $24 \mathrm{U} \cdot \mathrm{mg}^{-1}$ ) were used in this study. They were all purchased from Sigma-Aldrich, St. Louis, Missouri, USA; however, the enzymes were used without further purification. 

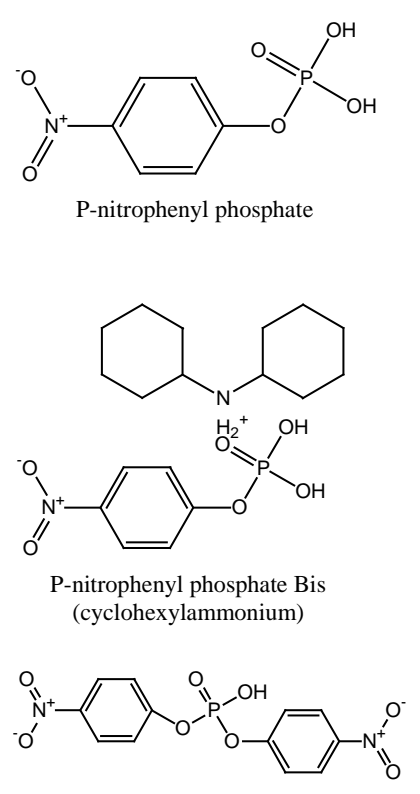

Bis p-nitrophenyl phosphate

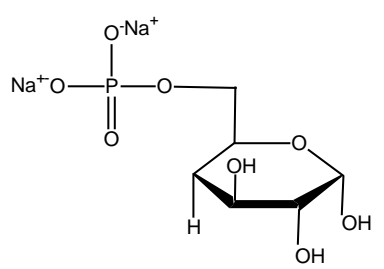

D-glucose 6-phosphate disodium salt

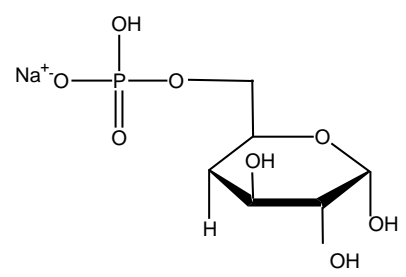

D-glucose 6-phosphate sodium salt
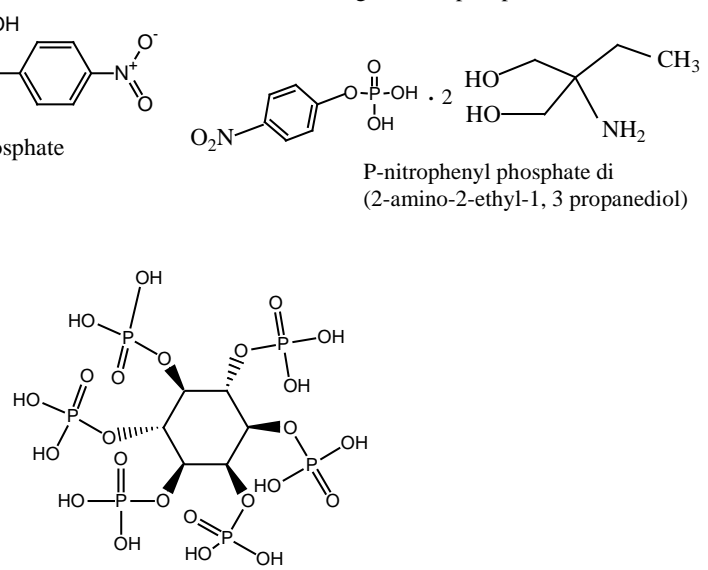

Phytic acid

Figure 1. Stereochemical structures of substrates.

\subsection{Assay Conditions}

The optimal $\mathrm{pH}$ for the phosphatases as reported by the supplier is 4.8 for acid phosphatase, and 10.4 for alkaline phosphatase, while the optimal temperature is $37^{\circ} \mathrm{C}$ for both acid and alkaline phosphatase. One unit (U) of the enzyme is reported to liberate $1.0 \mu \mathrm{mol}$ orthophosphate with the appropriate substrate at the appropriate $\mathrm{pH}$ and temperature. With acid and alkaline phosphatases, concentrations of $0.013-0.166 \mathrm{U} \cdot \mathrm{mL}^{-1}$ were used to hydrolyze the substrate. The effects of $\mathrm{pH}$, temperature, and time on each enzyme was determined by exposure to a wide range of temperatures ranging from $10^{\circ} \mathrm{C}$ to $80^{\circ} \mathrm{C}$; $\mathrm{pH}$ ranging from 2 to 9 , and time ranging from 1 to 10 hours using a substrate concentration of 5 times the $K_{\mathrm{m}}$ [33].

\subsection{Kinetic Determination}

To determine the kinetic parameters of each enzyme, each substrate (phosphate compound) analog was hydrolyzed at increasing concentrations with each enzyme at the supplier's reported $\mathrm{pH}$ and temperature for 1 hour. The substrate was dissolved in $100 \mathrm{mM}$ acetate buffer ( $\mathrm{pH} 4.8$ ) and a final enzyme concentration of 0.066, 0.013, and $0.166 \mathrm{U} \cdot \mathrm{mL}^{-1}$ for wheat germ, sweet potato, and potato respectively used for acid phosphatase hydrolysis. For alkaline phosphatase hydrolysis, each substrate was dissolved in $87 \mathrm{mM}$ glycine buffer, (pH 10.4) and a final enzyme concentration of $0.166 \mathrm{U} \cdot \mathrm{mL}^{-1}$ used. All reaction mixtures were carried out in a total volume of 3 $\mathrm{mL}$ and the reaction stopped using $10 \%$ sodium dodecyl sulfate at the end of the incubation period. The controls were set up by incubating the substrate without enzyme to correct for the Pi released due to chemical hydrolysis. The amount of Pi released was determined colorimetrically [34] and results plotted against substrate concentra- 
tions using the Michaelis-Mentenmodel $\left(\mathrm{V}=V_{\max }[\mathrm{S}] /[\mathrm{S}]+K_{\mathrm{m}}\right)$ which has been reported to account for the kinetic properties of several enzymes. The Michaelis-Menten constant $\left(K_{\mathrm{m}}\right)$, indicative of enzyme-substrate affinity; $V_{\max }$, the maximum reaction velocity at enzyme saturation; $K_{\text {cat }}$, ratio of $V_{\max }$ to concentration of active sites; and $K_{\mathrm{cat}} / K_{\mathrm{m}}$, the turnover number of an enzyme, were obtained from the linear regression fit of the MichaelisMenten equation (plots not shown). The $K_{\text {cat }} / K_{\mathrm{m}}$ is also the rate constant due to the interaction of substrate and enzyme and measures enzyme catalytic efficiency. Catalytic efficiency provides a better estimate of enzymesubstrate affinity than the $K_{\mathrm{m}}$. The value may be used to compare an enyme's preference for various substrates or in characterizing enzymes in pure systems where the actual enzyme concentration is known.

Chemical reaction rates generally double with every $10^{\circ} \mathrm{C}$ increase in temperature and is also known as temperature coefficient $\left(Q_{10}\right)$. The calculations [phosphatase activity at $T\left({ }^{\circ} \mathrm{C}\right) /$ phosphatase activity at $T\left({ }^{\circ} \mathrm{C}\right)-10^{\circ} \mathrm{C}$ ] to determine the temperature coefficients $\left(Q_{10}\right)$ were at $10^{\circ} \mathrm{C}$ intervals between 0 and $70^{\circ} \mathrm{C}$. When an enzyme reaction obeys the Arrhenius equation $\left[k=\mathrm{A}\right.$. $\left.\exp \left(-E_{\mathrm{a}} / R T\right)\right]$, the activation energy $\left(E_{\mathrm{a}}\right)$ or slope can be estimated from the logarithmic transformed equation $\left[\log k=\left(-E_{a} / 2.303 R T\right)+\log \mathrm{A}\right]$, where $k$ is the rate constant, $\mathrm{A}$ is the Arrhenius constant, $R$ is the gas constant $\left(8.314 \mathrm{~mol}^{-1} \cdot \mathrm{k}^{-1}\right)$, and $T$ is the temperature on the Kelvin scale.

\section{Results and Discussion}

\subsection{Activation Energies and Kinetic Parameters}

The Arrhenius plots were linear between $10^{\circ} \mathrm{C}$ and $50^{\circ} \mathrm{C}$ for acid phosphatase from wheat germ (Figure 2(a)), between $10^{\circ} \mathrm{C}$ and $70^{\circ} \mathrm{C}$ for acid phosphatase from sweet potato (Figure $2(\mathrm{~b})$ ), between $10^{\circ} \mathrm{C}$ and $60^{\circ} \mathrm{C}$ acid phosphatase from potato (Figure 2(c)), and between $10^{\circ} \mathrm{C}$ and $90^{\circ} \mathrm{C}$ for alkaline phosphatase (Figure 3). The calculated $E_{a}$ expressed in $\mathrm{kJ} \cdot \mathrm{mole}^{-1}$ ranged from 18.0 to 36.1 for acid phosphatase from wheat germ, 19.6 - 30.5 for acid phosphatase from sweet potato, 19.2 - 49.6 for acid phosphatase from potato, and 15.7 - 41.2 for alkaline phosphatase from $E$. coli (Table 1$)$. The average temperature coefficient $\left(Q_{10}\right)$ values, for acid phosphatase from wheat germ and potato between $20^{\circ} \mathrm{C}$ and $70^{\circ} \mathrm{C}$ ranged from 1.12 - 1.37 (Table 2) and 1.10 - 1.62 (Table 3) respectively, while the average $Q_{10}$ values for acid phosphatase from sweet potato between $20^{\circ} \mathrm{C}-90^{\circ} \mathrm{C}$ ranged from 1.03 - 1.19 (Table 4) and for alkaline phosphatase from E. coli ranged from 1.21 - 1.63 (Table 5).

The kinetic parameters calculated for the hydrolyzed substrates by acid phosphatase are shown in Table 6 and Table 7. The maximal rate $\left(V_{\max }\right)$ reveals the turnover number of an enzyme, which is the number of substrate molecules converted into products by an enzyme molecule in a unit time when the enzyme is fully saturated with substrate. The $K_{\text {cat }}$ reveals the turnover number of an enzyme and is equal to the kinetic constant. The higher the $K_{\text {cat }}$ value the greater the specificity of the enzyme in catalyzing the substrate. Berg et al. [35] reported that the $K_{\text {cat }}$ of most enzymes using their physiological substrates fall in the range of 1 to $10^{4} \mathrm{~s}^{-1}$. This study indicates the substrates can be divided into three groups (specific; less specific; and non-specific), based on their kinetic parameters. The specific group includes PNP, PNP2A2E, and PNPBC, less specific group includes DG6PNa, and DG6P2Na, and the non specific group includes Bis-PNP and phytate. Siddiqua et al. [36] considers $p$-NPP, phenyl phosphate, $\alpha$ - and $\beta$-naphthyl phosphate and $\beta$-glycerol phosphate preferable to phosphoamino acids, nucleoside phosphates and sugar phosphates for acid phosphatase.

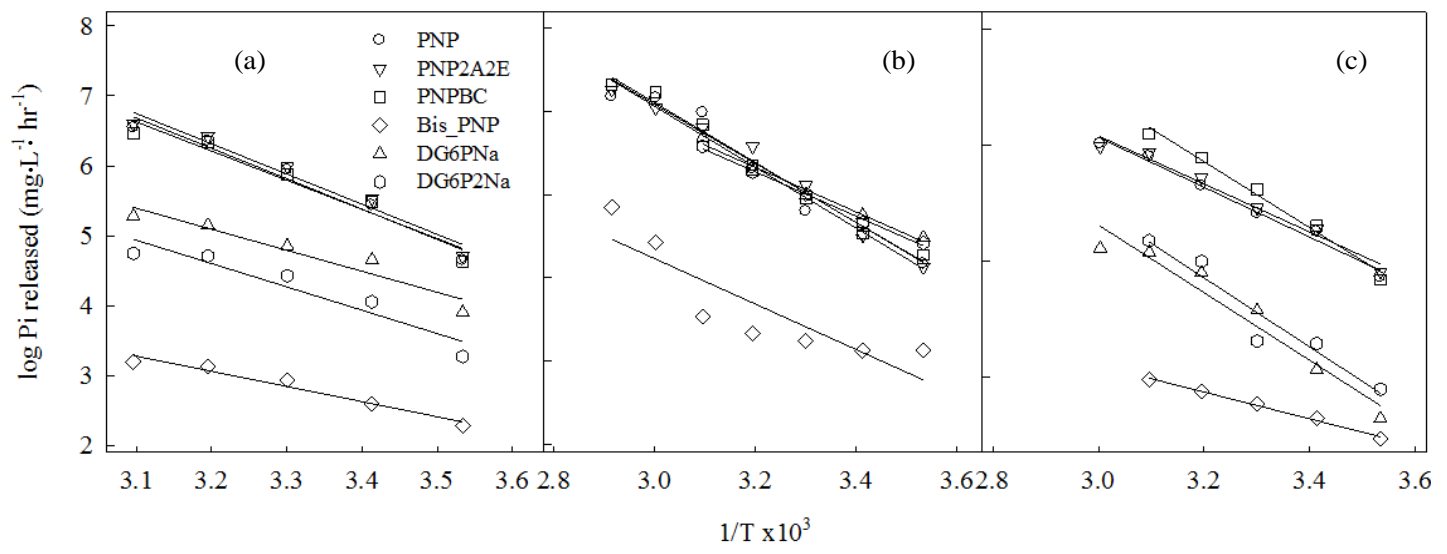

Figure 2. Arrhenius equation plot of acid phosphatase. (a) wheat germ; (b) sweet potato; (c) potato. 


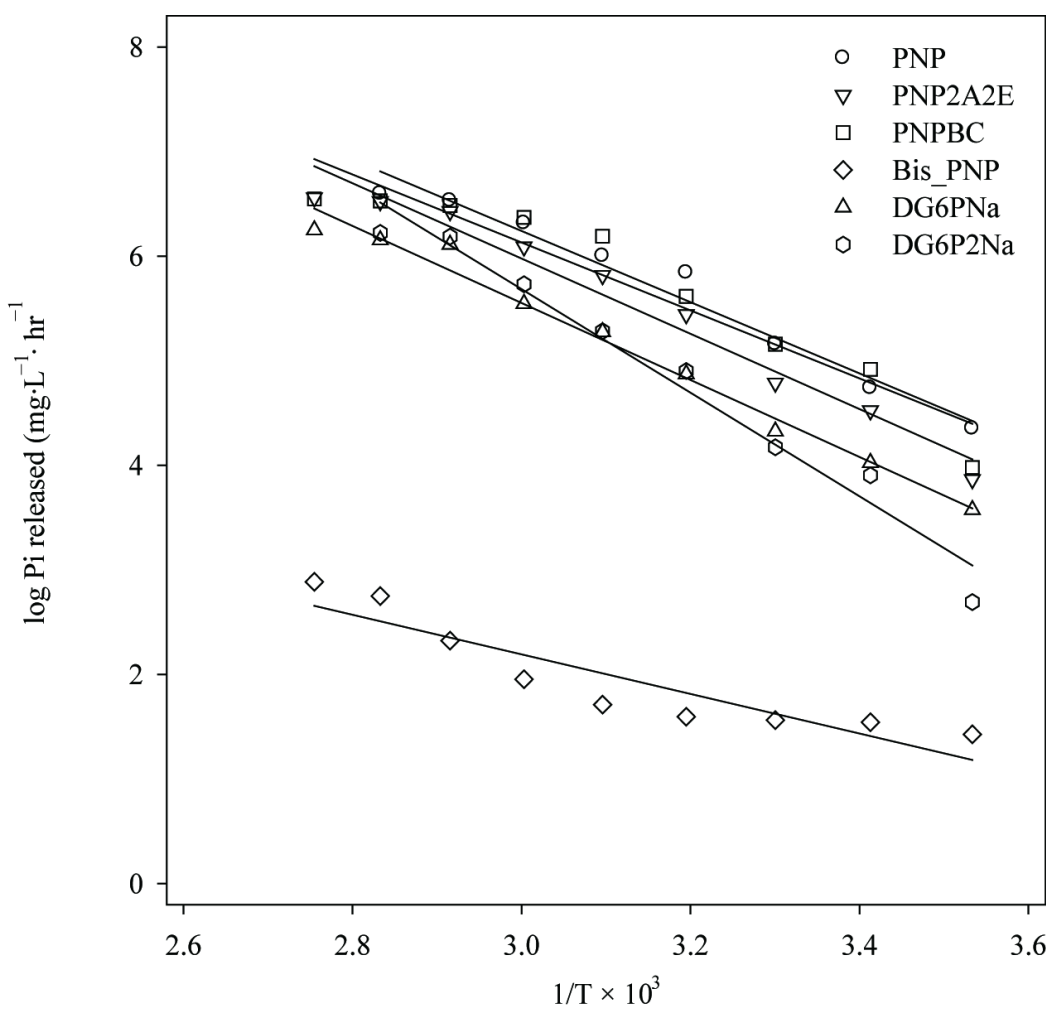

Figure 3. Arrhenius equation plot of alkaline phosphatase (E. coli) activity.

Table 1. Activation energy ( $\left.E_{\mathrm{a}}\right)$ values of acid and alkaline phosphatase activities.

\begin{tabular}{ccccc}
\hline & \multicolumn{2}{c}{ Acid phosphatase } & \multicolumn{2}{c}{ Alkaline phosphatase } \\
\cline { 2 - 5 } Substrate & Wheat germ & Sweet potato & Potato & E. coli \\
\cline { 2 - 5 } & & & $\mathrm{kJ} \cdot \mathrm{mol}^{-1}$ & 36.8 \\
PNP & 36.1 & 30.5 & 34.5 & 29.3 \\
PNP2A2E & 35.9 & 29.5 & 47.4 & 27.2 \\
PNPBC & 34.7 & 30.1 & 19.2 & 15.7 \\
Bis-PNP & 18.0 & 22.8 & 48.5 & 30.6 \\
DG6PNa & 25.0 & 19.6 & 49.6 & 41.2 \\
DG6P2Na & 27.8 & 22.3 & & \\
\hline
\end{tabular}

PNP ( $p$-nitrophenyl phosphate disodium hexahydrate); PNP2A2E (p-nitrophenyl phosphate di [2-amino-2-ethyl-1, 3 propanediol]); PNPBC ( $P$-nitrophenyl phosphate biscyclohexylammonium); Bis-PNP (Bis $p$-nitrophenyl phosphate sodium); DG6PNa (D-glucose 6-phosphate sodium salt); DG6P2Na (D-glucose 6-phosphate disodium hydrate).

Table 2. Temperature coefficients $\left(Q_{10}\right)$ of the acid phosphatase activity from wheat germ.

\begin{tabular}{ccccccccc}
\hline \multirow{2}{*}{ Substrate } & 20 & 30 & 40 & 50 & 60 & 70 & Mean \\
\cline { 2 - 9 }$y$ & & \multicolumn{2}{c}{50.75} & 0.74 & 1.34 \\
PNP & 2.20 & 1.65 & 1.51 & 1.21 & 0.75 & 0.88 & 1.37 \\
PNP2A2E & 2.28 & 1.58 & 1.54 & 1.19 & 0.76 & 0.73 & 0.80 & 1.35 \\
PNPBC & 2.37 & 1.48 & 1.58 & 1.14 & 0.73 & 0.69 & 1.12 \\
Bis-PNP & 1.37 & 1.41 & 1.21 & 1.10 & 0.92 & 0.49 & 1.12 \\
DG6PNa & 2.13 & 1.22 & 1.35 & 1.13 & 0.49 & 0.42 & 1.14 \\
DG6P2Na & 2.19 & 1.45 & 1.33 & 1.04 & 0.53 & 0.33 & \\
\hline
\end{tabular}

$Q_{10}=$ phosphatase activity at $T\left({ }^{\circ} \mathrm{C}\right) /$ phosphatase activity at $T\left({ }^{\circ} \mathrm{C}\right)-10{ }^{\circ} \mathrm{C}$, PNP (p-nitrophenyl phosphate disodium hexahydrate); PNP2A2E (p-nitrophenyl phosphate di [2-amino-2-ethyl-1,3propanediol]); PNPBC ( $P$-nitrophenyl phosphate biscyclohexylammonium); Bis-PNP (Bis $p$-nitrophenyl phosphate sodium); DG6PNa (D-glucose 6-phosphate sodium salt); DG6P2Na (D-glucose 6-phosphate disodium hydrate). 
Table 3. Temperature coefficients $\left(Q_{10}\right)$ of acid phosphatase activity from potato.

\begin{tabular}{ccccccccc}
\hline Substrate & 20 & 30 & 40 & 50 & 60 & 70 & Mean \\
\cline { 2 - 8 }$y$ & & & & ${ }^{\circ} \mathrm{C}$ & & & & \\
\hline PNP & 2.19 & 1.38 & 1.61 & 1.65 & 1.25 & 0.42 & 1.42 & 1.38 \\
PNP2A2E & 2.09 & 1.43 & 1.70 & 1.54 & 1.10 & 0.44 & 0.50 & 1.47 \\
PNPBC & 2.56 & 1.86 & 1.72 & 1.51 & 0.67 & 0.77 & 0.63 & 1.10 \\
Bis-PNP & 1.42 & 1.29 & 1.25 & 1.22 & 1.41 & 1.07 & 0.20 & 1.62 \\
DG6PNa & 2.32 & 2.78 & 1.92 & 1.41 & 0.57 & 1.61 \\
DG6P2Na & 2.2 & 1.05 & 3.95 & 1.43 & 0.43 & 0.57 \\
\hline
\end{tabular}

$Q_{10}=$ phosphatase activity at $T\left({ }^{\circ} \mathrm{C}\right) /$ phosphatase activity at $T\left({ }^{\circ} \mathrm{C}\right)-10^{\circ} \mathrm{C}$; PNP (p-nitrophenyl phosphate disodium hexahydrate); PNP2A2E ( $p$-nitrophenyl phosphate di [2-amino-2-ethyl-1,3propanediol]); PNPBC ( $P$-nitrophenyl phosphate biscyclohexylammonium); Bis-PNP (Bis $p$-nitrophenyl phosphate sodium); DG6PNa (D-glucose 6-phosphate sodium salt); DG6P2Na (D-glucose 6-phosphate disodium hydrate).

Table 4. Temperature coefficients $\left(Q_{10}\right)$ of acid phosphatase activity from sweet potato.

\begin{tabular}{|c|c|c|c|c|c|c|c|c|c|}
\hline \multirow{2}{*}{ Substrate } & 20 & 30 & 40 & 50 & 60 & 70 & 80 & 90 & Mean \\
\hline & \multicolumn{9}{|c|}{${ }^{\circ} \mathrm{C}$} \\
\hline PNP & 1.40 & 1.34 & 1.67 & 1.96 & 1.19 & 1.02 & 0.61 & 0.300 & 1.19 \\
\hline PNP2A2E & 1.46 & 1.83 & 1.59 & 1.25 & 1.26 & 1.25 & 0.39 & 0.47 & 1.19 \\
\hline PNPBC & 1.29 & 1.52 & 1.50 & 1.63 & 1.48 & 1.09 & 0.40 & 0.13 & 1.13 \\
\hline Bis-PNP & 1.00 & 1.12 & 1.10 & 1.22 & 2.44 & 1.52 & 0.42 & 0.40 & 1.15 \\
\hline DG6PNa & 1.31 & 2.27 & 1.35 & 1.50 & 0.91 & 0.27 & 0.85 & 0.77 & 1.03 \\
\hline DG6P2Na & 1.28 & 1.41 & 1.30 & 1.36 & 0.96 & 0.93 & 0.04 & 1.00 & 1.03 \\
\hline
\end{tabular}

$Q_{10}=$ phosphatase activity at $T\left({ }^{\circ} \mathrm{C}\right) /$ phosphatase activity at $T\left({ }^{\circ} \mathrm{C}\right)-10^{\circ} \mathrm{C}$.

Table 5. Temperature coefficients $\left(Q_{10}\right)$ of alkaline phosphstaseactivity from E. coli.

\begin{tabular}{cccccccccccc}
\hline Substrate & 20 & 30 & 40 & 50 & 60 & 70 & 80 & 90 \\
\cline { 2 - 8 } & & & & & ${ }^{\circ} \mathrm{C}$ & & & \\
PNP & 1.50 & 1.53 & 1.98 & 1.17 & 1.37 & 1.24 & 1.10 & 0.92 & 1.35 \\
PNP2A2E & 1.93 & 1.30 & 1.92 & 1.46 & 1.32 & 1.40 & 1.10 & 1.04 & 1.43 \\
PNPBC & 2.55 & 1.25 & 1.58 & 1.78 & 1.20 & 1.12 & 1.04 & 1.02 & 1.44 \\
Bis-PNP & 2.20 & 1.02 & 1.03 & 1.12 & 1.27 & 1.45 & 1.53 & 1.15 \\
DG6PNa & 1.57 & 1.35 & 1.73 & 1.49 & 1.31 & 1.76 & 1.04 & 1.10 \\
DG6P2Na & 3.36 & 1.31 & 2.08 & 1.46 & 1.57 & 1.58 & 1.04 & 0.67 \\
\hline
\end{tabular}

$Q_{10}=$ phosphatase activity at $T\left({ }^{\circ} \mathrm{C}\right) /$ phosphatase activity at $T\left({ }^{\circ} \mathrm{C}\right)-10^{\circ} \mathrm{C}$; PNP (p-nitrophenyl phosphate disodium hexahydrate); PNP2A2E ( $p$-nitrophenyl phosphate di [2-amino-2-ethyl-1, 3 propanediol]); PNPBC (P-nitrophenyl phosphate biscyclohexylammonium); Bis-PNP (Bis $p$-nitrophenyl phosphate sodium); DG6PNa (D-glucose 6-phosphate sodium salt); DG6P2Na (D-glucose 6-phosphate disodium hydrate).

Table 6. $V_{\max }, K_{\mathrm{m}}, K_{\text {cat }}, K_{\text {cat }} / K_{\mathrm{m}}$ values of acid phosphatase activities.

\begin{tabular}{|c|c|c|c|c|c|c|c|c|c|c|c|c|}
\hline & \multicolumn{4}{|c|}{ Wheat germ } & \multicolumn{4}{|c|}{ Sweet potato } & \multicolumn{4}{|c|}{ Potato } \\
\hline & $\begin{array}{c}V_{\max } \\
\left(\mathrm{mg} \cdot \mathrm{L}^{-1} \cdot \mathrm{hr}^{-1}\right)\end{array}$ & $\begin{array}{c}K_{\mathrm{m}} \\
(\mathrm{mM})\end{array}$ & $\begin{array}{c}K_{\text {cat }} \\
\left(\mathrm{hr}^{-1}\right)\end{array}$ & $\begin{array}{c}K_{\mathrm{cat}} / K_{\mathrm{m}} \\
\left(\mathrm{hr}^{-1} \cdot \mathrm{mM}^{-1}\right)\end{array}$ & $\begin{array}{c}V_{\max } \\
\left(\mathrm{mg} \cdot \mathrm{L}^{-1} \cdot \mathrm{hr}^{-1}\right)\end{array}$ & $\begin{array}{c}K_{\mathrm{m}} \\
(\mathrm{mM})\end{array}$ & $\begin{array}{c}K_{\text {cat }} \\
\left(\mathrm{hr}^{-1}\right)\end{array}$ & $\begin{array}{c}K_{\mathrm{cat}} / K_{\mathrm{m}} \\
\left(\mathrm{hr}^{-1} \cdot \mathrm{mM}^{-1}\right)\end{array}$ & $\begin{array}{c}V_{\max } \\
\left(\mathrm{mg} \cdot \mathrm{L}^{-1} \cdot \mathrm{hr}^{-1}\right)\end{array}$ & $\begin{array}{c}K_{\mathrm{m}} \\
(\mathrm{mM})\end{array}$ & $\begin{array}{c}K_{\text {cat }} \\
\left(\mathrm{hr}^{-1}\right)\end{array}$ & $\begin{array}{c}K_{\mathrm{cat}} / K_{\mathrm{m}} \\
\left(\mathrm{hr}^{-1} \cdot \mathrm{mM}^{-1}\right)\end{array}$ \\
\hline Phytate & 65 & 11.8 & 984 & 83 & 72.1 & 10.4 & 1803 & 173 & 165 & 14.0 & 330 & 24 \\
\hline PNP & 152 & 3.65 & 2303 & 631 & 135 & 2.69 & 10385 & 3861 & 143 & 4.53 & 861 & 190 \\
\hline PNP2A2E & 154 & 4.34 & 2333 & 538 & 130 & 3.32 & 10000 & 3012 & 162 & 4.58 & 976 & 213 \\
\hline PNPBC & 145 & 3.47 & 2197 & 633 & 126 & 2.25 & 9692 & 4308 & 166 & 5.00 & 1000 & 200 \\
\hline Bis-PNP & 5.21 & 2.20 & 78.9 & 36 & 5.35 & 6.92 & 409 & 59.0 & 2.73 & 2.26 & 17 & 7.50 \\
\hline DG6PNa & 38.8 & 5.16 & 588 & 114 & $223^{*}$ & 8.86 & 1343 & 152 & 44.61 & 3.20 & 269 & 84.0 \\
\hline DG6P2Na & 31.6 & 1.70 & 479 & 282 & $251^{*}$ & 11.13 & 1512 & 136 & 43.00 & 1.90 & 259 & 136 \\
\hline
\end{tabular}

PNP ( $p$-nitrophenyl phosphate disodium hexahydrate); PNP2A2E ( $p$-nitrophenyl phosphate di [-2-amino-2-ethyl ${ }^{-1}$, 3 propanediol]); PNPBC $(P$-nitrophenyl phosphate bis (cyclohexylammonium); Bis-PNP (Bis $p$-nitrophenyl phosphate sodium); DG6PNa (D-glucose 6-phosphate sodium salt); DG6P2Na (D-glucose 6-phosphate disodium hydrate); ${ }^{*}$ (0.166 U/ml of enzyme used). 
Table 7. $V_{\max }, K_{\mathrm{m}}, K_{\text {cat }}, K_{\text {cat }} / K_{\mathrm{m}}$ values of alkaline phosphatase (E. coli) activity.

\begin{tabular}{ccccc}
\hline Substrate & $V_{\max }\left(\mathrm{mg} \cdot \mathrm{L}^{-1} \cdot \mathrm{hr}^{-1}\right)$ & $K_{\mathrm{m}}(\mathrm{mM})$ & $K_{\text {cat }}\left(\mathrm{hr}^{-1}\right)$ & $K_{\text {cat }} / K_{\mathrm{m}}\left(\mathrm{hr}^{-1} \cdot \mathrm{mM}^{-1}\right)$ \\
\hline PNP & 216 & 6.55 & 1301 & 199 \\
PNP2A2E & 204 & 6.40 & 1229 & 192 \\
PNPBC & 198 & 5.79 & 1195 & 206 \\
Bis-PNP & nd & nd & nd & nd \\
DG6PNa & 88.5 & 4.87 & 533 & 110 \\
DG6P2Na & 82.8 & 5.50 & 499 & 91 \\
\hline
\end{tabular}

PNP ( $p$-nitrophenyl phosphate disodium hexahydrate); PNP2A2E (p-nitrophenyl phosphate di [-2-amino-2-ethyl ${ }^{-1}, 3$ propanediol]); PNPBC ( $p$-nitrophenyl phosphate bis (cyclohexylammonium); Bis-PNP (Bis $p$-nitrophenyl phosphate sodium); DG6PNa (D-glucose 6-phosphate sodium salt); DG6P2Na (D-glucose 6-phosphate disodium hydrate); nd: not determined.

The $K_{\mathrm{m}}$ value for acid phosphatase from sweet potato was the lowest $(2.25-3.32 \mathrm{mM})$ for the specific group while that of potato was the highest $(4.53-5.00 \mathrm{mM})$. For the specific group, a relatively low $K_{\mathrm{m}}$ value of 2.25 $\mathrm{mM}$ and $3.47 \mathrm{mM}$ were obtained for sweet potato and wheat germ respectively using PNPBC. For the specific group, the $K_{\text {cat }} / K_{\mathrm{m}}$ value for acid phosphatase from sweet potato was the highest $\left(3012-4308 \mathrm{~h}^{-1} \cdot \mathrm{mM}^{-1}\right)$ while that of potato was the lowest $\left(190-213 \mathrm{~h}^{-1} \cdot \mathrm{mM}^{-1}\right)$. The $K_{\text {cat }} / K_{\mathrm{m}}$ value of acid phosphatase from all species using PNPBC was greater than when PNP and PNP2A2E were used respectively. Acid phosphatase from sweet potato had the highest $K_{\text {cat }}$ values $\left(9692-10,385 \mathrm{~h}^{-1}\right.$ ) while acid phosphatase from potato had the lowest values (861 $1000 \mathrm{~h}^{-1}$ ) for the specific group (Table 6).

For the less specific group, acid phosphatase from sweet potato had the highest $K_{\mathrm{m}}$ values ranging from 8.86 $11.13 \mathrm{mM}$, and $K_{\text {cat }}$ values ranging from $1343-1512 \mathrm{~h}^{-1}$, than acid phosphatase from wheat germ and potato. Acid phosphatase from wheat germ and potato had low $K_{\mathrm{m}}$ values $\left(1.7\right.$ and $1.9 \mathrm{mM}$, and high values of $K_{\text {cat }} / K_{\mathrm{m}}$ of 282 and $84 \mathrm{~h}^{-1} \cdot \mathrm{mM}^{-1}$ respectively) with DG6P2Na than DG6PNa as substrate. The non-specific group showed little activity with acid phosphatase from all three species. Wyss et al. [38] reported a broad range of substrate hydrolysis with acid phosphatase from A. niger, but with little activity using phytic acid. The order of catalytic activity for the acid phosphatase was in the order: sweet potato $>$ wheat germ $>$ potato, while the order of substrate hydrolyzed was: PNPBC $>$ PNP $>$ PNP2A2E $>$ DG6P2Na $>$ DG6PNa $>$ Bis-PNP $>$ phytate.

Results showing the enzyme kinetics for alkaline phosphatase from $E$. coli are presented in Table 7 . The $K_{\mathrm{m}}$ values using PNPBC was lower than when PNP2A2E and PNP were used while the use of DG6PNa was lower than using DG6P2Na as substrate. The $K_{\text {cat }}$ values with PNP was greater than with PNP2A2E and PNPBC. The $K_{\text {cat }} / K_{\mathrm{m}}$ of E. coli with PNPBC was four units higher than with PNP, and fourteen units higher than with PNP2A2E. The $K_{\text {cat }}$ and $K_{\text {cat }} / K_{\mathrm{m}}$ value for alkaline phosphatase from E. coli on DG6PNa was higher than that of DG6P2Na. The order of substrate hydrolyzedwas: PNPBC > PNP > PNP2A2E > DG6PNa > DG6P2Na > Bis-PNP.

While other investigators [37] [39]-[43] [28] have reported $K_{\mathrm{m}}$ values for various substrates hydrolyzed by acid and alkaline phosphatase from various organisms, some of the values obtained in our study were higher than those reported which might be due to differences in substrate concentrations and the types and sources of the enzymes. The ratio $\left(K_{\mathrm{cat}} / K_{\mathrm{m}}\right)$ is used as a measure of catalytic efficiency and to compare an enzyme's preference for various substrates. Higher values indicate higher substrate preference by the enzyme. This study suggests that acid phosphatase has a preference for PNPBC than the traditionally used PNP.

\subsection{Effects of Time, Temperature, and $\mathrm{pH}$ on Activity}

Figure 4 shows the dephosphorylation of PNP, PNP2A2E, PNPBC, Bis-PNP, DG6PNa, and DG6P2Naby acid phosphatase with time. The activity of wheat germ acid phosphatase with time was linear for up to 3 hours with PNP, PNP2A2E, and PNPBC, DG6PNa, and DG6P2Na, up to 4 hours, while Bis-PNP was linear up to 10 hours (Figure 4(a)). The rate of hydrolysis of these substrates with sweet potato acid phosphatase was slightly different (Figure 4(b)). The rate of hydrolysis with PNP, PNP2A2E, and PNPBC was linear for up to 4 hours, while with DG6PNa, and DG6P2Na, it was linear for up to 6 hours, and with Bis-PNP up to 10 hours. Similar curves were observed when these substrates analogs were hydrolyzed with potato acid phosphatase (Figure 4(c)), except that Bis-PNP, DG6PNa, and DG6P2Na were linear up to 10 hours.

Hydrolysis of these substrates by E. coli alkaline phosphatase (Figure 5), shows that PNP, PNP2A2E, DG6- 


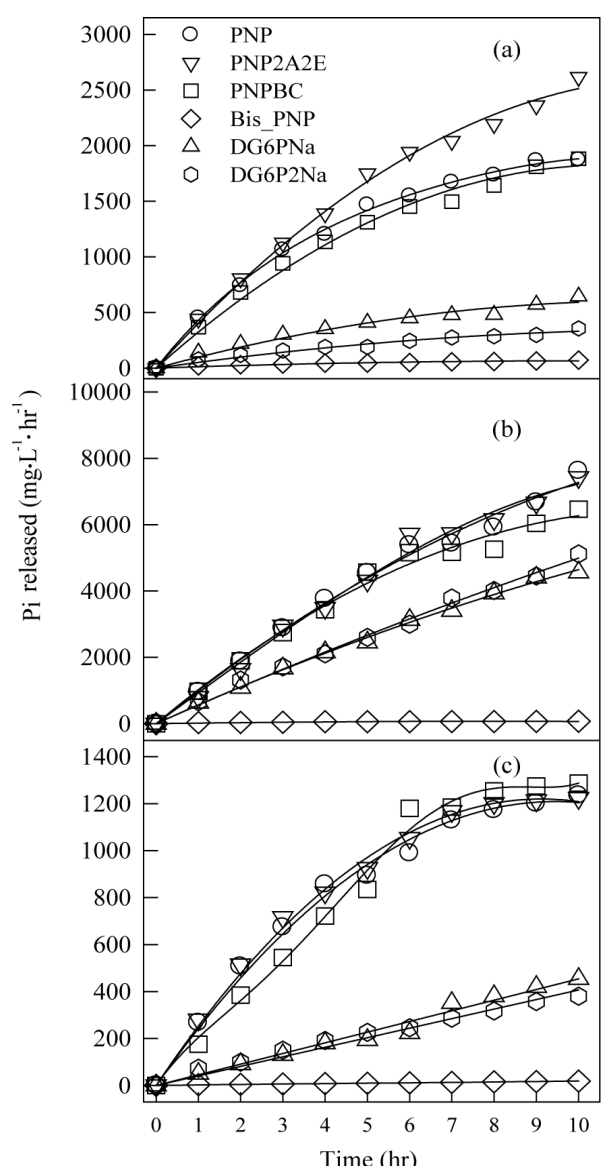

Figure 4. Effect of incubation time on acid phosphatase activity (a) wheat germ; (b) sweet potato; (c) potato.

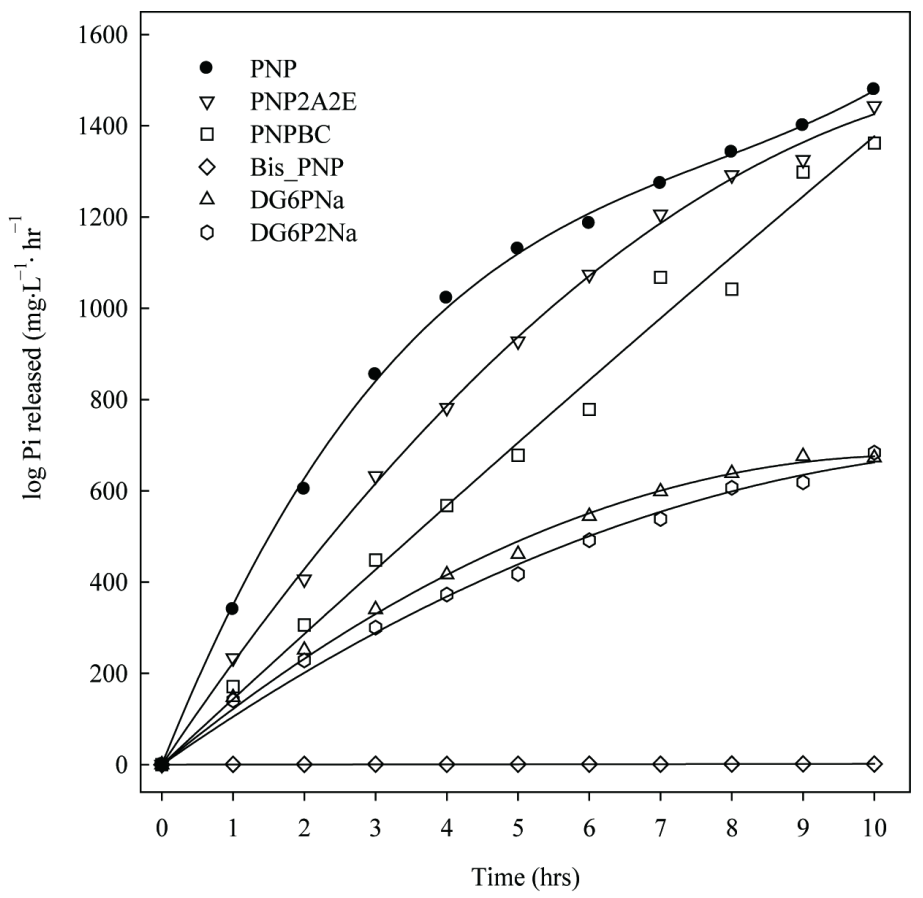

Figure 5. Effect of incubation time on alkaline phosphatase (E. coli) activity. 
PNa, and DG6P2Na were linear up to 3 hours while PNPBC and Bis-PNP were linear up to 10 hours. Nigam et al. [43] reported that $\beta$-glycerophosphate was linear for a much shorter time than phenyl-phosphate and $p$-nitrophenyl phosphate using human prostatic acid phosphatase. The time at which the curve begins to be non-linear indicates enzyme saturation or product inhibition. Our findings show that both acid and alkaline phosphatase have similar time course curve with PNP, PNP2A2E, PNPBC, and Bis-PNP. Similar findings was reported by Martin et al. [41] in which potato acid phosphatase and E. coli alkaline phosphatase showed similar time course with both L-tyrosine O-phosphate and 3-fluoro-DL-tyrosine O-phosphate. According to these investigators, potato acid phosphatase and E. coli alkaline phosphatase are known to hydrolyze phosphate esters of dissimilar structures with equivalent maximum velocities.

The optimum temperature for the acid phosphatase is shown in Figure 6. Wheat germ acid phosphatase optimum temperature was at $50^{\circ} \mathrm{C}$ (Figure 6(a)). Sweet potato acid phosphatase responded differently to temperature based on the substrate used. This enzyme was active for up to $70^{\circ} \mathrm{C}$ with PNP, PNP2A2E, PNPBC, and BisPNP, and $50^{\circ} \mathrm{C}$ with DG6PNa and DG6P2Na (Figure 6(b)). Potato acid phosphatase also responded differently to temperature depending on the substrate used. This enzyme was inactivated at temperatures above $50^{\circ} \mathrm{C}$
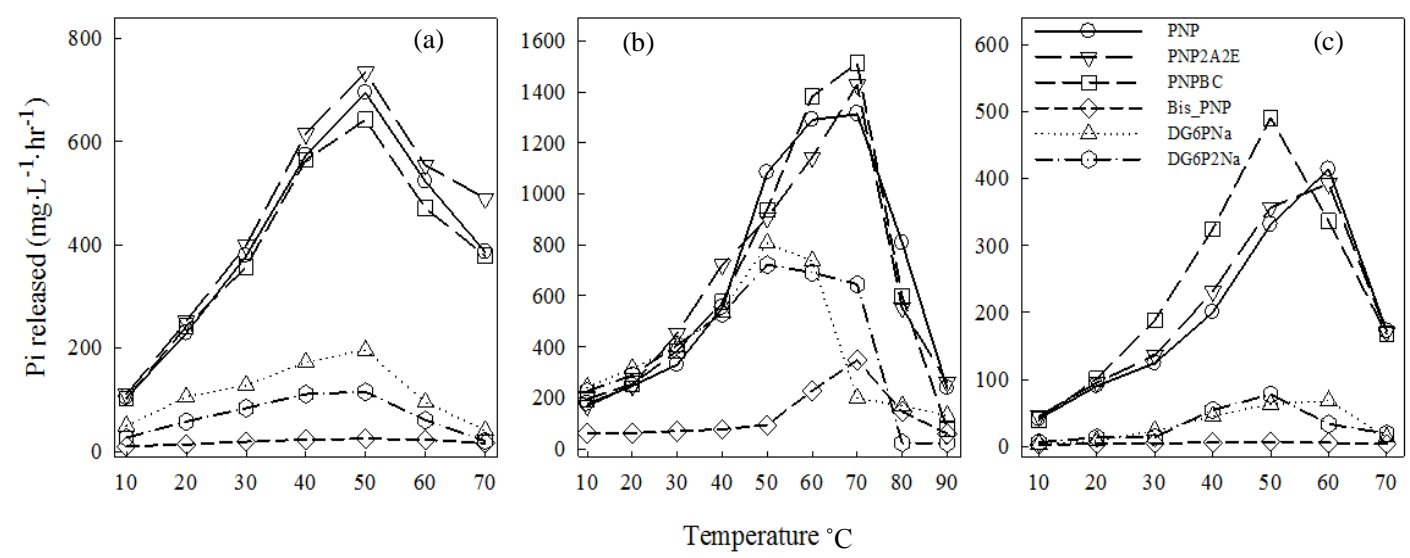

Figure 6. Effect of temperature on acid phosphatase. (a) wheat germ; (b) sweet potato; (c) potato.

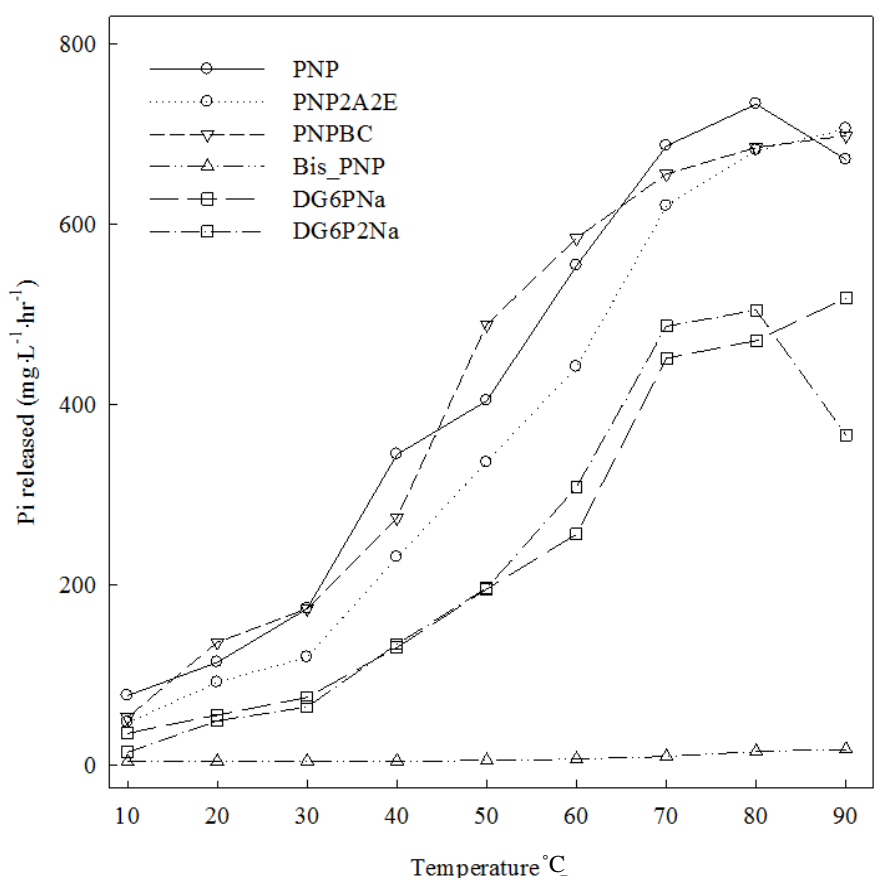

Figure 7. Effect of temperature on alkaline phosphatase. (E. coli) activity. 
with PNPBC and DG6P2Na, $60^{\circ} \mathrm{C}$ with PNP, PNP2A2E, and DG6PNa (Figure 6(c)). Asaduzzaman et al. [39] reported an optimum temperature of $55^{\circ} \mathrm{C}$ for a germinating Black Gram (Vignamungo L.) seedling whereas Siddiqua et al. [36] reported an optimum temperature of $40^{\circ} \mathrm{C}$ for Rohu fish liver acid phosphatase. The optimum temperature of activity for $E$. coli alkaline phosphatase was $80^{\circ} \mathrm{C}$ with PNP and DG6P2Na, $90^{\circ} \mathrm{C}$ with PNP2A2E, PNPBC, DG6PNa, and Bis-PNP (Figure 7).

The activity of each enzyme was also compared at various $\mathrm{pH}$ values (range, 2 - 9) using a concentration 5 times the $K_{\mathrm{m}}$ [33]. The $\mathrm{pH}$ for maximal hydrolysis of PNP, PNP2A2E, PNPBC, DG6PNa, and Bis-PNP by wheat germ acid phosphatase was 5.0 and 4.0 with DG6P2Na (Figure 8(a)). Sweet potato acid phosphatase showed a stable optimum $\mathrm{pH}$ between 5.0 and 6.0 for the hydrolysis of PNP, PNP2A2E, PNPBC, and Bis-PNP (Figure 8(b)). The optimum pH for the hydrolysis of DG6PNa was 6.0 and a pH of 5.0 using DG6P2Na (Figure 8(b)). These results are consistent with the findings by [39] [40] [43]-[45]. The $\mathrm{pH}$ optimum for potato acid phosphatase was 5.0 (Figure 8(c)).Escherichia coli alkaline phosphatase showed an optimal pH of 13.0 with PNP2A2E, PNPBC, and Bis-PNP, 10.0 with PNP, DG6PNa, and DG6P2Na (Figure 9), similar to the pH values reported by Cathala and Brunel [27] and Wilson et al. [46] but one unit higher than that reported by Mushak and Coleman [47]. The pH of alkaline phosphatase with PNP was two units higher than that reported by the supplier.
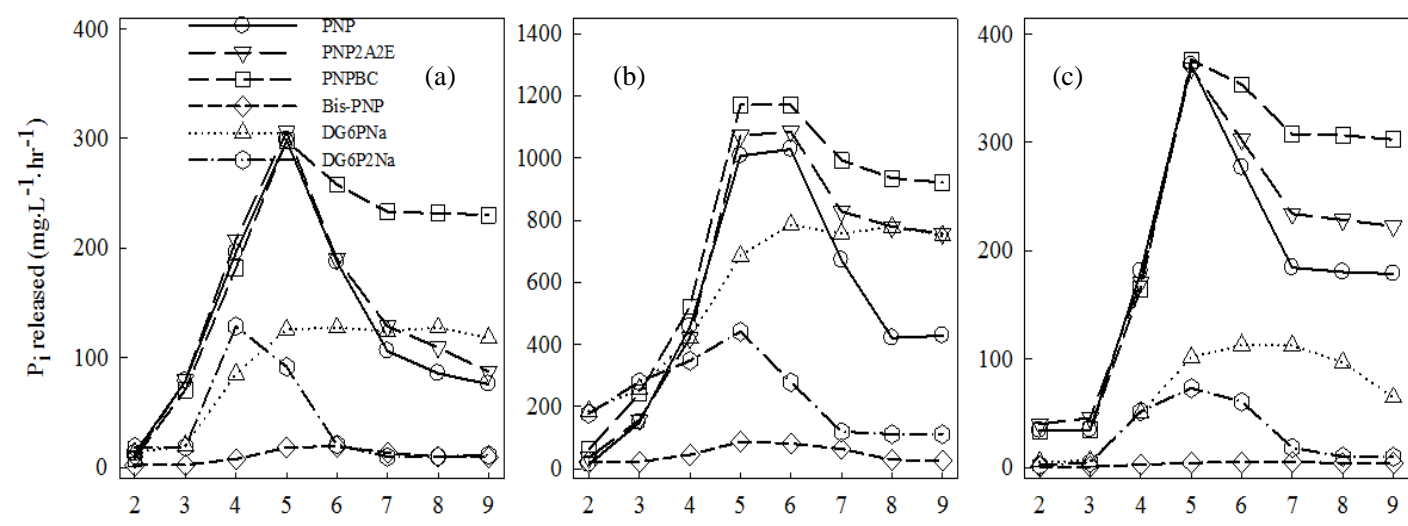

$\mathrm{pH}$

Figure 8. Effect of PH on acid phosphatase. (a) wheat germ; (b) sweet potato; (c) potato.

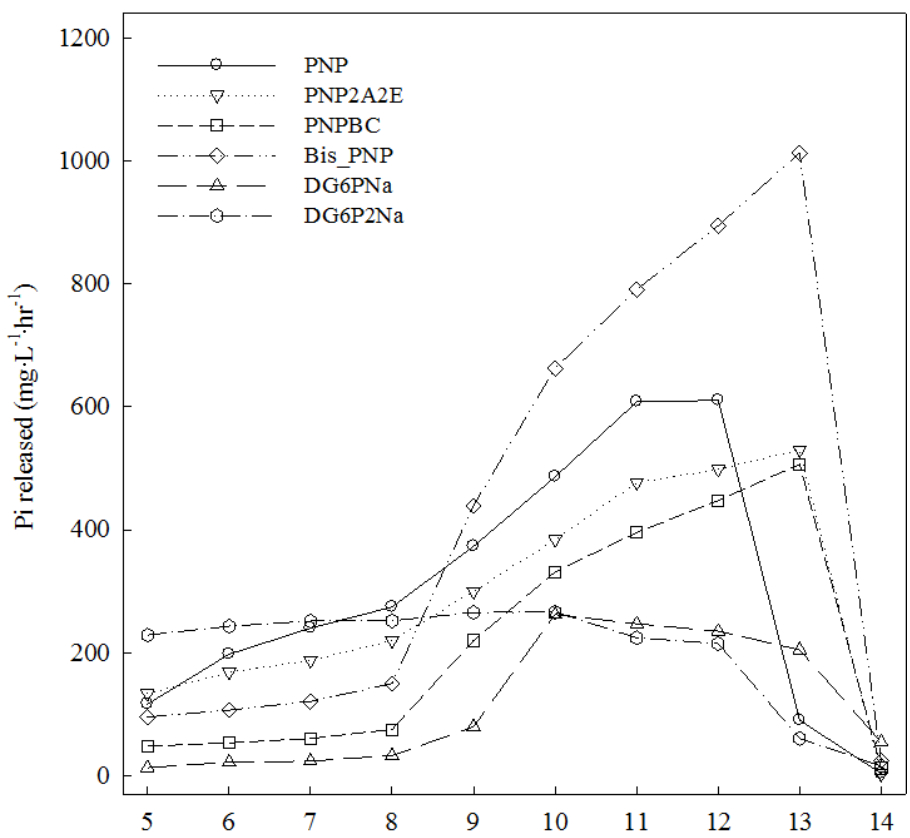

Figure 9. Effect of $\mathrm{pH}$ on alkaline phosphatase (E. coli) activity. 


\section{Conclusion}

Our study indicates that the rate of hydrolysis, catalytic efficiency, thermal stability, and optimal pH of these enzymes may depend on enzyme sources and the stereochemical or stereoisomeric structures of the substrates. This study also reveals that acid and alkaline phosphatases do exhibit a broad range of substrate hydrolysis with high affinity for PNPBC than the commonly used PNP. Sweet potato had relatively higher reaction kinetics ( $V_{\text {max }}, K_{\mathrm{m}}, K_{\text {cat }}, K_{\text {cat }} / K_{\mathrm{m}}$ ) values with most substrates tested. The order of catalytic activity for the acid phosphatase was in the order: sweet potato > wheat germ > potato, while the order of substrate hydrolyzed was: PNPBC > PNP $>$ PNP2A2E $>$ DG6P2Na $>$ DG6PNa $>$ Bis-PNP > phytate. The optimum pH for the acid phosphatase was observed to be 5.0. Alkaline phosphatase activity was similar to that of the acid phosphatase except that there was more alkaline phosphatase activity with DG6PNa than DG6P2Na.

\section{Acknowledgements}

This work is a contribution from the Winfred Thomas Agricultural Research Station, Alabama A\&M University, Normal, AL. Trade or manufacturers' names mentioned in the paper are for information only and do not constitute endorsement, recommendation, or exclusion by either Alabama A\&M University or USDA-ARS. The research was supported in part by USDA-NIFA, Evans-Allen Grant \# ALAX 011.

\section{References}

[1] Senwo, Z.N., Ranatunga, T.D., Tazisong, I.A., Taylor, R.W. and He, Z. (2007) Phosphatase Activity of Ultisols and Relationship to Soil Fertility Indices. Journal of Food Agriculture andEnvironment, 5, 262-266.

[2] Blair, R.M., Savin, M.C. and Chen, P.Y. (2014) Phosphatase Activities and Available Nutrients in Soil Receiving Pelletized Poultry Litter. Soil Science, 179, 182-189. http://dx.doi.org/10.1097/SS.0000000000000061

[3] Tazisong, I.A., Senwo, Z.N., Cade-Menun, B.J. and He, Z. (2014) Phosphorus Forms and Mineralization Potentials of Alabama Upland Cotton Production Soils Amended with Poultry Litter. In: He, Z.Q. and Zhang, H.L., Eds., Applied Manure and Nutrient Chemistry for Sustainable Agriculture and Environment, Springer Dordrecht Heidelberg, New York, London, 191-209. http://dx.doi.org/10.1007/978-94-017-8807-6_10

[4] Waldrip, H.M. and Acosta-Martínez, V. (2014) Phosphatase Activities and their Effects on Phosphorus Availability in Soils Amended with Livestock Manures. In: He, Z.Q. and Zhang, H.L., Eds., Applied Manure and Nutrient Chemistry for Sustainable Agriculture and Environment, Springer Dordrecht Heidelberg, New York, London, 123-140. http://dx.doi.org/10.1007/978-94-017-8807-6_7

[5] Webb, E.C. (1992) Enzyme Nomenclature. Academic Press, San Diego.

[6] He, Z.Q. and Honeycutt, C.W. (2001) Enzymatic Characterization of Organic Phosphorus in Animal Manure. Journal of Environmental Quality, 30, 1685-1692. http://dx.doi.org/10.2134/jeq2001.3051685x

[7] Pagliari, P.H. and Laboski, C.A.M. (2012) Investigation of the Inorganic and Organic Phosphorus Forms in Animal Manure. Journal of Environmental Quality, 41, 901-910. http://dx.doi.org/10.2134/jeq2011.0451

[8] Anderson, H. and Magdoff, F.R. (2005) Relative Movement and Soil Fixation of Soluble Organic and Inorganic Phosphorus. Journal of Environmental Quality, 34, 2228-2233. http://dx.doi.org/10.2134/jeq2005.0025

[9] Borie, F. and Rubio, R. (2003) Total and Organic Phosphorus in Chilean Volcanic Soils. Gayana Botánica, 60, 69-78. http://dx.doi.org/10.4067/s0717-66432003000100011

[10] Young, E.O., Ross, D.S., Cade-Menun, B.J. and Liu, C.W. (2013) Phosphorus Speciation in Riparian Soils: A Phosphorus-31 Nuclear Magnetic Resonance Spectroscopy and Enzyme Hydrolysis Study. Soil Science Society of America Journal, 77, 1636-1647. http://dx.doi.org/10.2136/sssaj2012.0313

[11] Zhu, Y., Wu, F., He, Z., Guo, J., Qu, X., Xie, F., Giesy, J.P., Liao, H. and Guo, F. (2013) Characterization of Organic Phosphorus in Lake Sediments by Sequential Fractionation and Enzymatic Hydrolysis. Environmental Science and Technology, 47, 7679-7687. http://dx.doi.org/10.1021/es305277g

[12] Hayes, J.E., Richardson, A.E. and Simpson, R.J. (2000) Components of Organic Phosphorus in Soil Extracts That Are Hydrolysed by Phytase and Acid Phosphatase. Biology and Fertility of Soils, 32, 279-286. http://dx.doi.org/10.1007/s003740000249

[13] Kerovuo, J., Rouvinen, J. and Hatzack, F. (2000) Analysis of Myo-Inositol Hexakisphosphate Hydrolysis by Bacillus Phytase: Indication of a Novel Reaction Mechanism. Biochemistry Journal, 352, 623-628. http://dx.doi.org/10.1042/0264-6021:3520623

[14] He, Z.Q., Honeycutt, C.W., Griffin, T.S., Larkin, R.P., Olanya, M. and Halloran, J.H. (2010) Increases of Soil Phos- 
phatase and Urease Activities in Potato Fields by Cropping Rotation Practices. Journal of Food Agriculture and Environment, 8, 1112-1117.

[15] Waldrip, H.M., He, Z.Q. and Erich, M.S. (2011) Effects of Poultry Manure Amendment on Phosphorus Uptake by Ryegrass, Soil Phosphorus Fractions and Phosphatase Activity. Biology and Fertility of Soils, 47, 407-418. http://dx.doi.org/10.1007/s00374-011-0546-4

[16] Waldrip, H.M., He, Z. and Griffin, T.S. (2012) Effects of Organic Dairy Manure on Soil Phosphatase Activity, Available Soil Phosphorus, and Growth of Sorghum-Sudangrass. Soil Science, 177, 629-637. http://dx.doi.org/10.1097/SS.0b013e31827c4b78

[17] Acosta-Martinez, V. and Waldrip, H.M. (2014) Soil Enzyme Activities as Affected by Manure Types, Application Rates and Management Practices. In: He, Z.Q. and Zhang, H.L., Eds., Applied Manure and Nutrient Chemistry for Sustainable Agriculture and Environment, Springer Dordrecht Heidelberg, New York and London, 99-122. http://dx.doi.org/10.1007/978-94-017-8807-6_6

[18] Li, S.M., Li, L., Zhanh, F.S. and Tang, C. (2004) Acid Phosphatase Role in Chickpea/Maize Intercropping. Annals of Botany, 94, 297-303. http://dx.doi.org/10.1093/aob/mch140

[19] Acosta-Martinez, V., Dowd, S.E., Sun, Y., Wester, D. and Allen, V. (2010) Pyrosequencing Analysis for Characterization of Bacterial Diversity in a Soil as Affected by Integrated Livestock-Cotton Production Systems. Applied Soil Ecology, 45, 13-25. http://dx.doi.org/10.1016/j.apsoil.2010.01.005

[20] He, Z.Q., Griffin, T.S. and Honeycutt, C.W. (2004) Enzymatic Hydrolysis of Organic Phosphorus in Swine Manure and Soil. Journal of Environmental Quality, 33, 367-372. http://dx.doi.org/10.2134/jeq2004.3670

[21] He, Z.Q., Olk, D.C., Honeycutt, C.W. and Fortuna, A.M. (2009) Enzymatically- and Ultraviolet-Labile Phosphorus in Humic Acid Fractions from Rice Soils. Soil Science, 174, 81-87. http://dx.doi.org/10.1097/SS.0b013e3181981dc5

[22] Johnson, N.R. and Hill, J.E. (2010) Phosphorus Species Composition of Poultry Manure-Amended Soil Using High-Throughput Enzymatic Hydrolysis. Soil Science Society of America Journal, 74, 1786-1791. http://dx.doi.org/10.2136/sssaj2009.0431

[23] Johnson, N.R. and Hill, J.E. (2011) High-Throughput Measurement and Classification of Organic P in Environmental Samples. Journal of Visualized Experiments, 52, 1-3. http://dx.doi.org/10.3791/2660

[24] Strickland, J.D.H. and Solorzano, L. (1966) Determination of Monoesterase Hydrolysable Phosphate and Phosphomonoesterase Activity in Sea Water. In: Barnes, H., Ed., Some Contemporary Studies in Marine Science, Allen G. and Unwin, London, 665-674.

[25] Vincent, J.B., Crowder, M.W. and Averill, B.A. (1992) Hydrolysis of Phosphate Monoesters: A Biological Problem with Multiple Chemical Solutions. Trends in Biochemical Science, 17, 105-110. http://dx.doi.org/10.1016/0968-0004(92)90246-6

[26] Cathala, G. and Brunel, C. (1975) Bovine Kidney Alkaline Phosphatase. Journal of Biological Chemistry, 250, 60466053.

[27] Tabatabai, M.A. and Bremner, J.M. (1969) Use of P-Nitrophenyl Phosphate for Assay of Soil Phosphatase Activity. Soil Biology Biochemistry, 1, 301-307. http://dx.doi.org/10.1016/0038-0717(69)90012-1

[28] Joner, E.J., van Aarde, I.M. and Vosatka, M. (2000) Phosphatase Activity of Extra-Radical Arbuscular Mycorrhizal Hyphae: A Review. Plant and Soil, 226, 199-210. http://dx.doi.org/10.1023/A:1026582207192

[29] Tazisong, I.A., He, Z. and Senwo, Z.N. (2013) Inorganic and Enzymatically Hydrolyzable Organic Phosphorus of Alabama Decatur Silt Loam Soils Cropped with Upland Cotton. Soil Science, 178, 231-239. http://dx.doi.org/10.1097/SS.0b013e31829cf464

[30] Tazisong, I.A., Senwo, Z.N., Taylor, R.W. and He, Z. (2008) Hydrolysis of Organic Phosphates by Commercially Available Phytases: Biocatalytic Potentials and Effects of Ions on their Enzymatic Activities. Journal of Food Agriculture and Environment, 6, 500-505.

[31] He, Z.Q., Honeycutt, C.W., Cade-Menun, B.J., Senwo, Z.N. and Tazisong, I.A. (2008) Phosphorus in Poultry Litter and Soil: Enzymatic and Nuclear Magnetic Resonance Characterization. Soil Science Society of America Journal, 72, 1425- 1433. http://dx.doi.org/10.2136/sssaj2007.0407

[32] He, Z.Q., Olk, D.C. and Cade-Menun, B.J. (2011) Forms and Lability of Phosphorus in Humic Acid Fractions of Hord Silt Loam Soil. Soil Science Society of America Journal, 75, 1712-1722. http://dx.doi.org/10.2136/sssaj2010.0355

[33] Malcolm, R.E. (1982) Assessment of Phosphatase Activity in Soils. Soil Biology Biochemistry, 15, 403-408. http://dx.doi.org/10.1016/0038-0717(83)90003-2

[34] Murphy, J. and Riley, J.P. (1962) A Modified Single Solution Method for Determination of Phosphate in Natural Waters. Analytica Chimica Acta, 27, 31-36. http://dx.doi.org/10.1016/S0003-2670(00)88444-5

[35] Berg, J.M., Tymoczko, J.L. and Stryer, L. (2003) Biochemistry. W.H Freeman and Company, New York. 
[36] Siddiqua, A., Saeed, A., Naz, R., Sherazi, M., Abbas, S. and Saeed, A. (2012) Purification and Biochemical Properties of Acid Phosphatase from Robu Fish Liver. International Journal of Agriculture and Biology, 14, 223-228.

[37] Wyss, M., Brugger, R., Kronenberger, A., Remy, R., Fimbel, R., Oesterhelt, G., Lehmann, M. and van Loon, A.P.G.M. (1998) Biochemical Characterization of Fungal Phytases (Myo-Inositol Hexakisphosphate Phosphohydrolases): Catalytic Properties. Applied Environmental Microbiology, 65, 367-373.

[38] Asaduzzaman, A.K.M., Rahman, M.H. and Yeasmin, T. (2011) Purification and Characterization of Acid Phosphatase from a Germinating Black Gram (Vignamungo L.) Seedling. Archives of Biological Science, 63, 747-756. http://dx.doi.org/10.2298/ABS1103747A

[39] Scott, E.M. (1966) Kinetics Comparison of Genetically Different Acid Phosphatases of Human Erythrocytes. Journal of Biological Chemistry, 241, 3049-3052.

[40] Turner, B.L., Baxter, R., Ellwood, N.T.W. and Whitton, B.A. (2001) Characterization of the Phosphatase Activities of Mosses in Relation to their Environment. Plant, Cell and Environment, 24, 1165-1176. http://dx.doi.org/10.1046/j.1365-3040.2001.00767.x

[41] Martin, B., Pallen, C.J., Wang, J.H. and Graves, D.J. (1985) Use of Fluorinated Tyrosine Phosphate to Probe the Substrate Specificity of the Low Molecular Weight Phosphate Activity of Calcineurin. Journal of Biological Chemistry, 260, 14932-14937.

[42] Wagschal, K., Franqui-Espiet, D., Lee, C.C., Robertson, G.H. and Wong, D.W.S. (2005) Enzyme-Couple Assay for $\beta$-Xylosidase Hydrolysis of Natural Substrates. Applied and Environmental Microbiology, 71, 5318-5323. http://dx.doi.org/10.1128/AEM.71.9.5318-5323.2005

[43] Nigam, V.N., Davidson, H.M. and Fishman, W.H. (1959) Kinetics of Hydrolysis of the Orthophosphate Monoesters of Phenol, P-Nitrophenol, and Glycerol by Human Prostatic Acid Phosphatase. Journal of Biological Chemistry, 234, 1550-1554.

[44] Barbara, K.J. and Grisolia, S. (1960) Purification and Properties of a Nonspecific Acid Phosphatase from Wheat Germ. Journal of Biological Chemistry, 235, 2278-2281.

[45] Denu, J.M. and Dixson, J.E. (1995) A Catalytic Mechanism for the Dual-Specific Phosphatase. Proceedings of the National Academy of Sciences of the United States of America, 92, 5910-5914. http://dx.doi.org/10.1073/pnas.92.13.5910

[46] Wilson, I.B., Dayan, J. and Cyr, K. (1964) Some Properties of Alkaline Phosphatase from Escherichia coli. Journal of Biological Chemistry, 239, 4182-4184.

[47] Mushak, P. and Coleman, J.E. (1972) Hydrolysis of a Stable Oxygen Ester of Phosphorothioic Acid by Alkaline Phosphatase. Biochemistry, 11, 201-205. http://dx.doi.org/10.1021/bi00752a009 